\title{
SPATIAL Distribution OF LARGE WOODY DEBRIS on the Snake River, Grand Teton National Park
}

\author{
RICHARD A. MARSTON $\uparrow$ OKLAHOMA STATE UNIVERSITY $\uparrow$ STILLWATER \\ ROBIN D. GRAY $\downarrow$ UNIVERSITY OF WYOMING $\downarrow$ LARAMIE
}

\section{$\downarrow \quad$ INTRODUCTION}

Large woody debris (LWD) plays a key role in controlling the ecology and geomorphology of streams. Woody debris traps coarse particulate organic matter and sediments (Andersen and Sedell, 1979; Bilby and Likens, 1980; Marston, 1982); provides habitat for aquatic insects (Angermeier and Karr, 1984; Benke et al., 1985); and provides cover in pools and slow water areas (Bisson et al., 1982, 1987; Tschaplinski and Hartman, 1983; Fausch and Northcote, 1992). The role of wood in affecting stream morphology is dependent on the size of the stream (Bilby and Ward, 1989). In smaller streams, woody debris can create step pool sequences (Heede, 1972, 1985; Marston, 1982), increase pool area (Murphy and Hall, 1981; Ralph et al., 1994), and reduce sediment transport (Bilby, 1984). Nakamura and Swanson (1993) noted that the importance of woody debris to the morphology of first order streams can be limited by the size of the debris, which is often large enough to bridge the channel and not interact with the flow. Woody debris plays a larger role when it enters the channel bottom, where it can divert flow and affect erosion and deposition.

The scale issues raised by Bilby and Ward (1989) and Nakamura and Swanson (1993) are critical to understanding the role of woody debris. To date, LWD has not been adequately studied at watershed scales in larger rivers. In fact, there is little understanding of the relationship between LWD and the geomorphic pattern of the river channel (Piegay and Marston, 1998; Piegay and Gurnell, 1997; Piegay, 1993). The purpose of this study is to document the distribution of LWD jams on the Snake River in Grand Teton National Park, Wyoming in order to understand the effects of LWD on channel morphology in large river systems.

\section{$\downarrow \quad$ STUdY AREA}

Our study area encompassed the Snake River from Jackson Lake to Moose, Wyoming (Figure 1). This section, approximately $42.0 \mathrm{~km}$ (26.1 $\mathrm{mi})$ in length, lies entirely within Grand Teton National Park. The area was further divided into five reaches (Marston 1992). Channel unit type, bankfull water-depth, size distribution of streambed particles, channel gradient, floodplain width and total sinuosity were used to distinguish the sections (Table 1). Reach 1 extends $6.7 \mathrm{~km}$ from Jackson Lake Dam to Pacific Creek. This reach is characterized by a low gradient, single channel dominated by pools with fine-sized particles. Reach 2 continues from Pacific Creek to Sagebrush Island. This is a $6.53 \mathrm{~km}$ segment characterized by pronounced braiding among mid-channel bars with a stream bed dominated by coarse gravel and small cobbles. The third reach extends $10.41 \mathrm{~km}$ from Sagebrush Island to Deadman's Bar in a single channel dominated by a small cobble substrate. Reach 4 continues from Deadman's Bar to Frustration Ponds. This $6.18 \mathrm{~km}$ section is a predominantly braided pattern. Lastly, reach 5 extends $11.91 \mathrm{~km}$ from Frustration Ponds to Moose in a steep-gradient, compound channel. Major tributaries entering the Snake River within the study area are Pacific Creek, Buffalo Fork, and Spread Creek. 


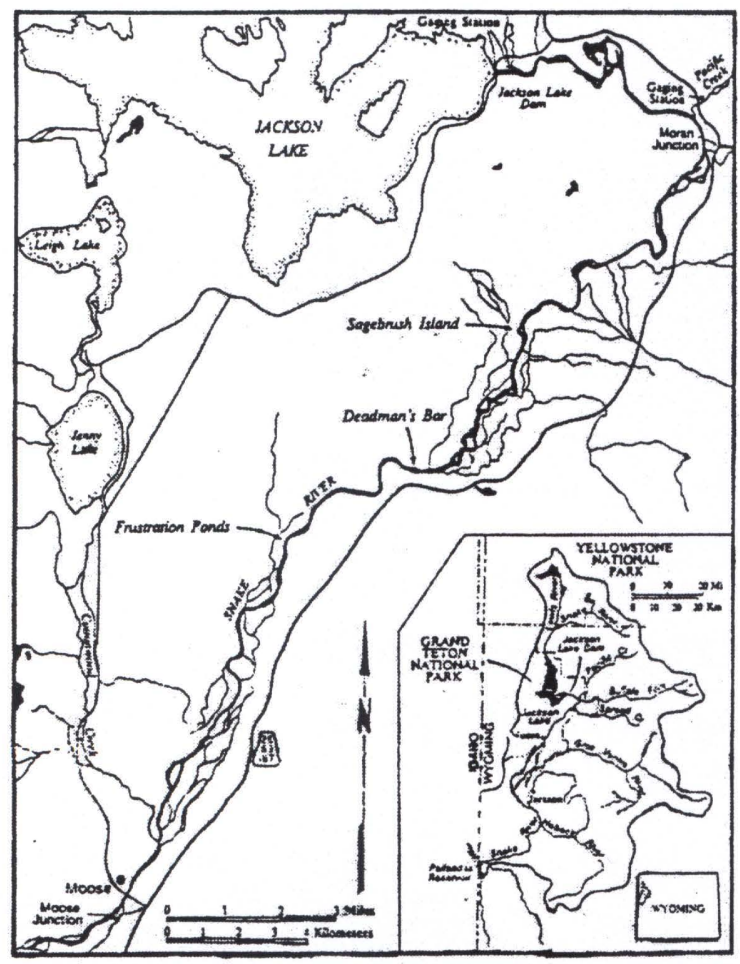

Figure 1. The Snake River study area.

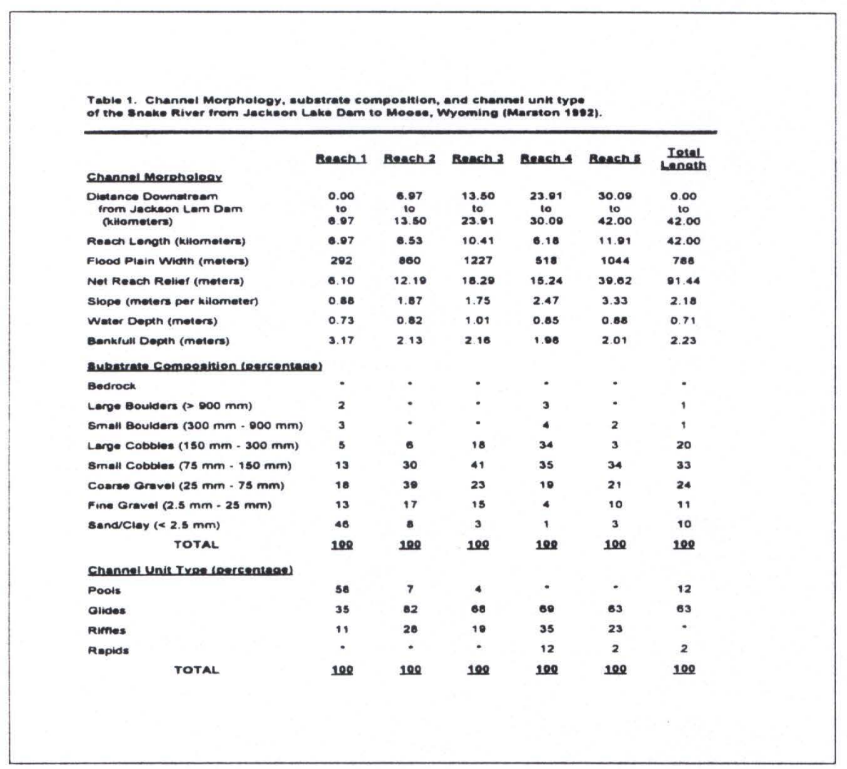

The 100-year floodplain of the Snake River between the dam and Moose covers an area of 31.9 square kilometers (7883 acres). This area was unaffected by the 1988 fires. Floodplain vegetation within the study area is dominated by blue spruce (Picea pungens), narrowleaf cottonwood (Populus angustifolia), lodgepole pine (Pinus contorta), and mountain alder (Alnus incana).

\section{METHODS}

We performed the field portion of this study in June 1999. During this time the Snake River was at or near bankfull depth with streamflows varying from around $4000 \mathrm{cfs}$ at Moran, Wyoming to 12,000 cfs at Moose, Wyoming. We collected data from the main channel and adjacent river banks and channel bars only. Side channels were excluded from the scope of this study.

We performed detailed measurements on 41 in-channel LWD accumulations at ten locations. We defined LWD as any woody debris greater than 10 $\mathrm{cm}$ in diameter and $1 \mathrm{~m}$ in length lying entirely within the main channel at bankfull depth. LWD jams or accumulations were defined as two or more pieces of LWD. We measured the length and width of all major axes within these accumulations and recorded the number of pieces, number of rootwads, predominant orientation (parallel or perpendicular to stream), predominant species, and decay class (Grette 1985). In addition, we noted any LWD pieces containing beaver-cut markings.

All main channel LWD accumulations within the study reaches were mapped using a Magellan Nav Pro 6000 global positioning system and 1:24,000 USGS quadrangles. For each accumulation we recorded the following parameters: (1) Number of LWD pieces within the jam classified as single (1), double (2-3), multiple (4-10) or extensive (>10); (2) Percentage of the bankfull channel width the jam occupied recorded in five categories; $0-5 \%, 5 \%$ $20 \%, 20 \%-40 \%, 40 \%-60 \%,>60 \%$; (3) Decay class based on the presence/absence of green or dead needles, bark and primary/secondary limbs (Grette, 1985); (4) Orientation relative to the thalweg.

To determine the potential for large woody debris recruitment, we mapped and recorded several streamside vegetation and bank geomorphology variables. Bank measurements included counts of all fallen and tilted trees ( $>10$ degrees) within $5 \mathrm{~m}$ of the bankfull mark. To determine the extent of bank erosion, the height of the bank cut was recorded in 5 classes; $0-14.9 \mathrm{~cm}, \quad 15 \mathrm{~cm}-29.9 \mathrm{~cm}, 30 \mathrm{~cm}-59.9 \mathrm{~cm}$, $60 \mathrm{~cm}-89.9 \mathrm{~cm}$ and $>90 \mathrm{~cm}$ and exposed roots noted. Beaver activity including lodge building and tree cutting were also recorded.

As part of our preliminary analysis, we used linear regression to examine the relationships between LWD jam size (area or number of pieces) and debris jam composition (age of pieces, presence of root wads, etc.). We then used Chi-square goodness 
of fit tests to explore the relationship between the composition of LWD accumulations and their position along the study reach (Cox 1996). We also compared the distribution of LWD jams throughout the study reaches using Chi-square tests.

\section{$\downarrow \quad$ RESULTS}

For the 41 in-channel jams measured, the total number of LWD pieces ranged from 3 to 75 , with a mean of 12 . Jam sizes ranged from $18.36 \mathrm{~m}^{2}$ to $693 \mathrm{~m}^{2}$, averaging $165 \mathrm{~m}^{2}$. All jams contained at least one rootwad. The species composition of the LWD was evenly distributed between spruce and cottonwood.

Because of its extreme size $\left(693 \mathrm{~m}^{2}\right.$ with 75 pieces) relative to all other jams, one jam was excluded from regression analyses. Regression analysis revealed a strong relationship $\left(r^{2}=0.542, \mathrm{p}<0.001\right)$ between the number of LWD pieces and the number of rootwads within our measured jams (Figure 2). A strong relationship $\left(r^{2}=0.683, p<0.001\right)$ was also identified between the total number of pieces within the measured jam and the total size of the jam (Figure 3). There was also a relationship $\left(r^{2}=0.499\right.$, $\mathrm{p}<0.001$ ) between the number of rootwads and the total size of the measured jam.

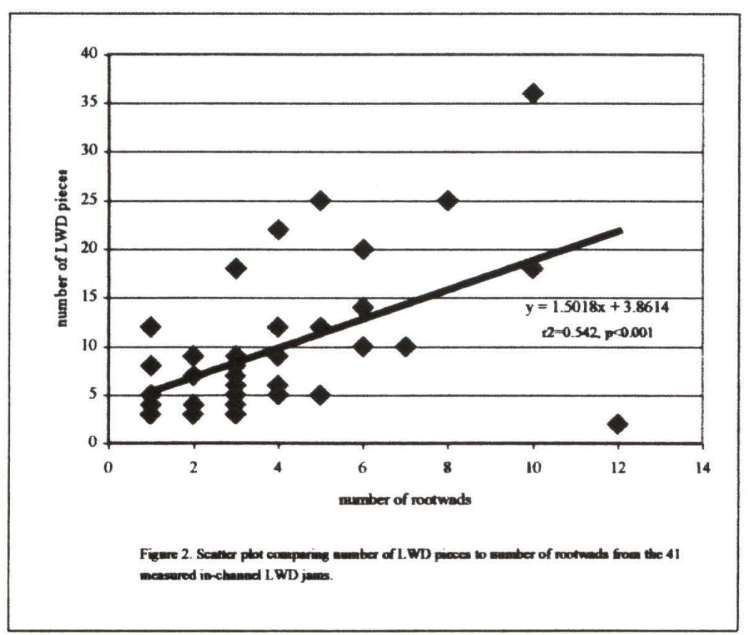

More than 500 occurrences of in-channel LWD were identified on the $42.0 \mathrm{~km}$ long study section (Table 2), $23 \%$ of which were LWD jams ( 2 or more pieces). Chi-square tests revealed significant differences $(p<0.001)$ in the number of debris between study reaches. Reach 2 had the highest num- ber of LWD in all categories while Reach 1 had the least. Over $85 \%$ of all jams contained at least one rootwad. Essentially all accumulations were oriented parallel to the thalweg; the exceptions were mostly located in pools.

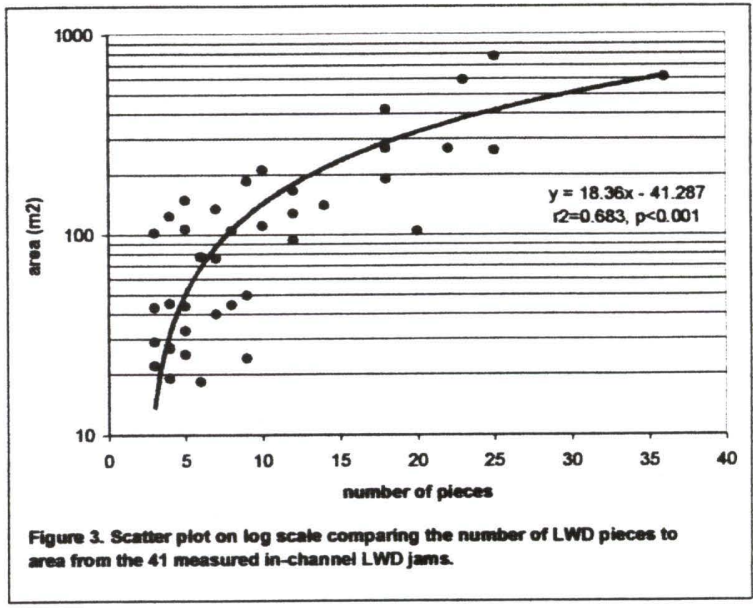

Table 2. Total number of $L W D$ pieces by rach and accumulation type.

\begin{tabular}{|c|r|r|r|r|r|r|r|}
\hline Reach & $\begin{array}{r}\text { Single } \\
(1 \mathrm{pc})\end{array}$ & $\begin{array}{c}\text { Double } \\
(2-3 \text { pcs. })\end{array}$ & $\begin{array}{c}\text { Multiple } \\
(4-10 \\
\text { pcs. })\end{array}$ & $\begin{array}{c}\text { Extensive } \\
(>10 \\
\text { pcs. })\end{array}$ & Total & $\begin{array}{r}\text { Reach } \\
\text { Length } \\
(\mathrm{km})\end{array}$ & $\begin{array}{c}\text { Total per } \\
\mathrm{km}\end{array}$ \\
\hline 1 & 0 & 0 & 0 & 0 & 0 & 6.97 & 0.00 \\
\hline 2 & 162 & 27 & 34 & 21 & 244 & 6.53 & 37.37 \\
\hline 3 & 95 & 13 & 6 & 6 & 120 & 10.41 & 11.53 \\
\hline 4 & 41 & 8 & 2 & 4 & 55 & 6.18 & 8.90 \\
\hline 5 & 110 & 7 & 9 & 11 & 137 & 11.91 & 11.50 \\
\hline Total & 408 & 55 & 51 & 42 & 556 & 42.00 & 13.24 \\
\hline
\end{tabular}

Fallen and tilted trees along the banks were primarily blue spruce. Most downed and tilted trees resulted from bank undercutting. We found beavercut trees almost exclusively in cottonwood stands.

Initial analysis comparing geomorphology (Marston 1992) to LWD distributions revealed increases in LWD accumulations as the frequency of riffles/rapids increased, and as the frequency of fallen/tilted trees increased. The size of LWD jams was highest where channel shifting was minimal.

\section{$\downarrow \quad$ DISCUSSION}

All of the LWD jams measured and more than $85 \%$ of LWD recorded contained at least one rootwad, indicating the importance of these structures in LWD jam formation. The rootwad provides a foundation and acts as an anchor for developing jams. Bank undercutting provides the primary recruitment method for LWD rootwads, with some rootwads entering the system through in-flowing tributaries. Unlike wood recruited through bank erosion, beaver-cut wood lacks the structure needed to 
serve as a foundation for subsequent LWD jam formation. Since bank undercutting is needed for the recruitment of these rootwads, we can expect LWD jams to increase in areas with high bank erosion.

Jackson Lake Dam plays an important role in LWD distribution, preventing LWD from entering the system from Jackson Lake. We would, therefore, expect LWD jams to increase as the distance from the dam increases. Initial Chi-square tests reveal significant differences in the size and number of LWD jams between reaches, however debris jams do not increase with downstream distance as expected. In fact, reach 2 had the highest number of total accumulations. This suggests other factors must play a role in LWD distribution. Areas of high bank erosion and tributary inflows increase LWD recruitment into the system. However, these variables cannot predict the spatial distribution of jams. Transport by streamflow as well as by geomorphic factors, such as channel unit type, sinuosity, bankfull depth and width may all be significant in determining LWD locations. Initial analyses indicate channel shifting may play an important role in size and location of jams. Without channel shifting LWD accumulations increase in size because LWD transport over time is concentrated.

Data from the June 1999 study period indicate that streamside vegetation recruitment and channel morphology play a significant role in LWD jam size and distribution. Rootwads are a necessary component in initiating jam formation, while streamside vegetation and tributaries provide the debris needed. Further analyses are needed to determine the relationships of between debris jam distribution and stream channel morphology.

\section{$\uparrow \quad$ ACKNOWLEDGEMENTS}

This research was made possible through funding from the University of Wyoming - National Park Service Research Grant Program, the University of Wyoming's Arts and Sciences Independent Study Award and the Rumsey Bissell Marston Scholarship. We thank the staff at the UW-NPS Research Center for assisting in all aspects of the project. Additional Thanks go to Stephen Gray for his invaluable assistance with both data collection and analysis and to Bryce Marston in helping to collect field data.

\section{$\downarrow$ Literature Cited}

Anderson, N. H., and Sedell, J. R., 1979. Detritus processing by macroinvertebrates in stream ecosystems. Ann. Rev. Entomology 24:351357.

Angermeier, P. L., and Karr, J. R., 1984. Relationships between woody debris and fish habitat in a small warm water stream. Trans. American Fisheries Soc. 113:716-726.

Benke, A. C., Henry, III, R. L., Gillespie, D. M., and Hunter, R. J., 1985. Importance of snag habitat for animal production in southeastern streams. Fisheries 10:8-13.

Bilby, R. E., and Likens, G. E., 1980. Importance of organic debris dams in the structure and function of stream ecosystems. Ecology 61:1107-1113.

Bilby, R.E. 1984. Role of organic debris in regulating the export of dissolved and particulate matter from a forested watershed. Ecology 62:1234-1243.

Bilby, R. E., and Ward, J. W., 1989. Changes in characteristics and function of woody debris with increasing size of streams in western Washington. Trans. American Fisheries Soc. 118:368-378.

Bisson, P. A., Nielsen, J. L., Palmason, R. A., and Grove, L. E., 1982. A system of naming habitat types in small streams, with examples of habitat utilization by salmonids during low streamflow. In: N. A. Armatrout (Editor), Acquisition and utilization of aquatic habitat inventory information: Proceedings of a Symposium, Portland OR, Oct. 1981. Western Division, American Fisheries Society, Bethesda, MD, pp. 62-73.

Cox, G.W. 1996. Laboratory Manual for General Ecology. Wm. C. Brown Publishers, Dubuque, IA, 278pp.

Fausch, K. D., and Northcote, T. G., 1992. Large woody debris and salmonid habitat in a small coastal British Columbia stream. Canadian J.Fisheries and Aquatic Science 49:682-693. 
Grette, G.B. 1985. The role of large organic debris in juvenile salmon rearing habitat in small streams. University of Washington, Seattle, Wash. M.S. thesis.

Heede, B. H., 1972. Influences of a forest on the hydraulic geometry of two mountain streams. Water Resources Bulletin 8:523-530.

Heede, B. H., 1985. Channel adjustments to the removal of log steps: an experiment in a mountain stream. Env. Management 9:427432.

Marston, R.A., 1982. The geomorphic significance of log steps in forest streams. Annals Assoc. American Geographers 72:99-108

Marston, R.A. 1992. Changes in geomorphic processes in the Snake River following impoundment of Jackson Lake and potential changes due to 1988 fires in the watershed. Annual Report to University of WyomingNational Park Service Research Center. 103 pp.

Murphy, M. L., and Hall, J. D., 1981. Varied effects of Clear-cut logging on predators and their habitat in small streams of the Cascade Mountains, Oregon. Canadian J. Fisheries Aquatic Science 38:137-145.

Nakamura, F., and Swanson, F. J., 1993. Effects of coarse woody debris on morphology and sediment storage of a mountain stream system in western Oregon. Earth Surface Processes and Landforms 18:43-61.
Piegay, H. 1993. Nature, mass and preferential sites of coarse woody debris deposits in the Lower Ain Valley (Mollon Reach), France. Regulated Rivers: Research and Management 8:359-372.

Piegay, H. and Gurnell, A.M. 1997. Large woody debris and river geomorphologic pattern: examples from S.E. France and S. England. Geomorphology 19:99-116.

Piegay, H. and Marston, R.A. 1998. Distribution of large woody debris along the outer bend of meanders in the Ain River, France. Physical Geography 19:318-340.

Ralph, S. C., Poole, G. C., Conquest, L. L., and Naiman, R. J., 1994. Stream channel morphology and woody debris in logged and unlogged basins of western Washington. Canadian J. Fisheries and Aquatic Science 51:37-51.

Tschaplinski, P. J., and Hartman, G. F., 1983. Winter distribution of juvenile Coho salmon (Oncorhynchus kisutch) before and after logging in Carnation Creek, British Columbia, and some implications for overwinter survival. Canadian J. Fisheries and Aquatic Science 40:452-461. 